\title{
A preliminary study of the ocular hypotensive effects of bromocriptine in diabetic patients with autonomic
} neuropathy

\author{
M.R. Al-Sereiti*, P. Turner and E.A.M. Gale' \\ Department of Clinical Pharmacology and 'Department of Diabetes and Immunogenetics, \\ St Bartholomew's Hospital, London ECIA $7 B E, U K$
}

\begin{abstract}
Summary: The effect of bromocriptine on intraocular pressure has been investigated in a group of 8 diabetic patients with autonomic neuropathy, to test the hypothesis that bromocriptine exerts its ocular hypotenisve action through presynaptic dopamine receptors. Bromocriptine eye drops $(0.025 \%)$ produced a significant fall in intraocular pressure in a control group of 8 matched normal volunteers, but this effect was not seen in the eyes of the diabetic patients. These results are consistent with a presynaptic site of action of bromocriptine.
\end{abstract}

\section{Introduction}

Several dopamine receptor agonists, including bromocriptine, lergotrile and pergolide, have been shown to produce dose- and time-related ocular hypotension in rabbits and monkeys. ${ }^{1}$ Bromocriptine, lisuride and pergolide have also been shown to reduce intraocular pressure (IOP) in healthy volunteers. ${ }^{2-4}$ The role of $D_{2}$-receptors in this ocular hypotensive action was demonstrated by pretreating healthy volunteers with intravenous metoclopramide, which completely abolished the fall in IOP produced by oral bromocriptine without itself influencing IOP when given alone. ${ }^{5}$

The anatomical site of these $D_{2}$ receptors in man is not known. In rabbits, the ocular hypotensive actions of bromocriptine and pergolide were abolished by superior cervical gangliomectomy, ${ }^{6}$ which suggested that the dopamine receptors involved were located on the presynaptic neurone. We have investigated the effects of bromocriptine on IOP in a group of diabetic patients with autonomic neuropathy and compared them with healthy controls matched for age, sex and eye colour.

\section{Methods}

Eight patients (6 males) from the diabetic clinic in this hospital, already diagnosed as having type I or type II diabetes mellitus, volunteered for the study, which had been approved by the local ethics

Correspondence: Professor P. Turner, M.D., B.Sc., F.R.C.P., F.F.P.M.

*Present address: Faculty of Medicine, Tripoli, Libya. Accepted: 25 October 1990 committee. Their mean age was 54 years (range 39-61). They had been screened for evidence of autonomic neuropathy and were found to be positive in one or more of the following tests of autonomic function: ${ }^{7}$

1. heart-rate variation during deep breathing, calculated from a continuous electrocardiographic (ECG) tracing during 6 successive deep breaths;

2. immediate heart-rate response to standing, using a continuous ECG tracing;

3. blood-pressure response to standing, using the Dinamap vital signs monitor, 1846;

4. blood-pressure response to sustained grip, using a sphygmomanometer with its cuff replaced by an inflatable bag as a handgrip dynamometer.

Pupillary responses to darkness, expressed as the ratio (\%) of pupil: iris diameter after 1 minute in total darkness, were measured by photography using a Polaroid U-5 Close-Up Land camera with a built-in flash, 1:3 ratio multiplier and frame. ${ }^{8}$ IOP was measured by non-contact tonometry.,10

The results in the diabetic patients were compared with those of a group of normal subjects matched as far as possible for age, sex and eye colour ( 4 males, mean age 46 years, range $35-62$ years).

All subjects were treated with 2 drops of bromocriptine mesylate $0.025 \%$ in their left eyes at $13.00 \mathrm{~h}$. IOP was measured in both eyes just before and at 2 and $3 \mathrm{~h}$ after instillation.

\section{Results}

The results of the autonomic function tests in the 8 diabetic patients are shown in Table I. All patients 
Table I Results of the autonomic function tests. Lower limits of abnormality for darkness pupil diameter/iris (\%) were those described by Smith and Dewhirst. ${ }^{8}$ Normal, borderline and abnormal values of tests of cardiovascular function were those described by Ewing and Clarke ${ }^{7}$

\begin{tabular}{|c|c|c|c|c|c|c|c|}
\hline Subject & $\begin{array}{c}\text { Age } \\
\text { (years) }\end{array}$ & Sex & $\begin{array}{c}\text { Pupil } \\
\text { diameter in } \\
\text { darkness/iris } \\
(\%)\end{array}$ & $\begin{array}{c}\text { Heart-rate } \\
\text { variation during } \\
\text { deep breathing } \\
\text { (beats/min) }\end{array}$ & $\begin{array}{c}\text { Immediate } \\
\text { heart-rate } \\
\text { response to standing } \\
(30: 15 \text { ratio })\end{array}$ & $\begin{array}{c}\text { Immediate systolic } \\
B P \text { response to } \\
\text { standing } \\
(\mathrm{mmHg})\end{array}$ & $\begin{array}{c}\text { Diastolic BP } \\
\text { response to hand- } \\
\text { grip dynamometer } \\
(\mathrm{mmHg})\end{array}$ \\
\hline 1 & 55 & $\mathbf{M}$ & $39.70^{*}$ & $8^{* \bullet}$ & 1.05 & 5 & 20 \\
\hline 2 & 59 & $\mathbf{M}$ & $26.80^{* *}$ & $3^{* *}$ & 1.05 & 9 & 29 \\
\hline 3 & 44 & $\mathbf{M}$ & 54.50 & $10^{* *}$ & 1.10 & -5 & $9^{* *}$ \\
\hline 4 & 59 & M & $37.29^{* *}$ & $2^{* *}$ & $1.00^{* *}$ & $25^{*}$ & $15^{\circ}$ \\
\hline 5 & 54 & $\mathbf{F}$ & 49.13 & $1^{* *}$ & 1.08 & 10 & 39 \\
\hline 6 & 39 & M & 48.57 & $3 *$ & $1.00^{* *}$ & $24^{*}$ & $7^{* *}$ \\
\hline 7 & 60 & $\mathbf{F}$ & 39.22 & $3^{* *}$ & $1.03^{*}$ & $17^{*}$ & 36 \\
\hline 8 & 61 & M & 53.09 & $6^{* *}$ & 1.16 & 8 & 23 \\
\hline
\end{tabular}

"Borderline; "*abnormal. Subjects 2, 4 and 7 have insulin-dependent diabetes. The others have insulin-independent diabetes. $\mathbf{B P}=$ blood pressure.

had abnormal heart-rate responses to deep breathing, and several showed abnormalities in other tests. Two patients had abnormal and one a borderline response to pupillary diameter to total darkness. $^{8}$

The mean (SEM) IOP responses to instillation of bromocriptine are shown in Figure 1. Two-way analysis of variance, comparing post-treatment with baseline measurements, showed that bromocriptine had no effect on IOP in the diabetic patients, but that the ocular hypotensive action in the normal subjects was significant $(P<0.002)$ at 2 and $3 \mathrm{~h}$ in the treated eye but not in the contralateral eye.

\section{Discussion}

This study has confirmed that local instillation of bromocriptine eye drops has a significant ocular hypotensive action in normal volunteers, ${ }^{11}$ and has shown, for the first time, that this effect was not seen in the eyes of patients with evidence of autonomic neuropathy. While all patients had at least one abnormality of autonomic function, including cardiovascular reflexes (Table I), only 3 of 8 patients had pupillary responses that would be considered abnormal by the criteria of Smith and Dewhirst. ${ }^{8}$ The question arises, therefore, whether the absent, or at least reduced, effect of bromocriptine in the diabetic patients is associated with their diabetic condition rather than with its ocular neuropathic complications. It might be argued that this could be answered by studying a group of diabetic patients without evidence of autonomic neuropathy. However, we have already shown ${ }^{12}$ that the mean IOP value of a population of diabetic patients was significantly higher than that of their matched controls when compared overall, while that of a subgroup of these patients with evidence of autonomic neuropathy was not significantly different from their matched controls. It may be, therefore, that an abnormality of IOP control


$+P<0.002$ compared with pretreatment values

Figure 1 Changes in intraocular pressure after 2 drops ( 5 min apart) of bromocriptine $0.025 \%$ instilled in the left eyes of diabetic patients with autonomic neuropathy $(O)$ and normal volunteers $(O)$. Each point is the mean of intraocular pressure measurements obtained from 8 subjects. Vertical bar represents SEM. 
exists in diabetic patients whether or not they have other evidence of autonomic neuropathy, and that this abnormality is associated with a resistance to the ocular hypotensive action of bromocriptine.

On the other hand, it is also possible that the change in IOP control in diabetic patients itself represents another and more prevalent component of autonomic neuropathy, and that the abnormal response to bromocriptine is part of it. If so, then our results support the hypothesis that bromocriptine reduces IOP by an action on presynaptic $\mathrm{D}_{2}$ receptors. The mechanism underlying the raised IOP in diabetic patients and the change that accompanies the development of other evidence of autonomic neuropathy require further investigation, probably involving longitudinal studies of IOP and autonomic function in larger numbers of diabetic patients.

\section{References}

1. Potter, D.E. \& Burke, J.A. Effect of ergoline derivatives on intraocular pressure and iris function in rabbits and monkeys. Current Eye Research 1983, 2: 281-288.

2. Mekki, Q.A., Hassan, S.M. \& Turner, P. Bromocriptine lowers intraocular pressure without affecting blood pressure. Lancet 1983, i: $1250-1251$.

3. Mekki, Q.A., Warrington, S.J. \& Turner, P. Bromocriptine eye drops lower intraocular pressure without affecting prolactin levels. Lancet 1984, i: $287-288$.

4. Al-Sereiti, M.R. \& Turner, P. The effect of lisuride, terguride and bromocriptine on intraocular pressure. Br J Clin Pharmac 1989, 27: 159-163.

5. Mekki, Q.A. \& Turner, P. Stimulation of dopamine receptors (type 2) lowers human intraocular pressure. $\mathrm{Br} \mathrm{J} \mathrm{Ophthalmol}$ 1985, 69: 909-910.

6. Potter, D.E., Burker, J.A. \& Chang, F.W. Ocular hypotensive action of ergoline derivatives in rabbits; effects of sympathectomy and domperidone pretreatment. Current Eye Research 1984, 3: 307-314.
Although the means and ranges of ages of the patients and their controls did not differ significantly $(P=0.1)$, it is possible that some of the difference of effect of bromocriptine might be accounted for by the small difference in mean age, as impaired autonomic function occurs with increasing frequency with advancing age. ${ }^{13}$ Further studies of dopamine agonists in larger numbers of diabetic patients should, therefore, ensure a closer matching of ages of patients and their normal controls.

\section{Acknowledgements}

Sandoz Pharmaceuticals UK provided lyophilized bromocriptine mesylate.

7. Ewing, D.J. \& Clark, B.F. Diagnosis and management of diabetic autonomic neuropathy. $\mathrm{Br} M e d \mathrm{~J}$ 1982, 285: 916-918.

8. Smith, S.A. \& Dewhirst, R.R. A simple diagnostic test for pupillary abnormality in diabetic autonomic neuropathy. Diabetic Med 1986, 3: 38-41.

9. Grolman, B. A new tonometer system. Am J Optometry Physiol Opt 1972, 49: 646-650.

10. Shields, M.B. The non-contact tonometer - its value and limitations. Surv Ophthalmol 1980, 24: 211-219.

11. Turner, P. Bromocriptine, dopamine and glaucoma. Postgrad Med J 1986, 62: 819-820.

12. Al-Sereiti, M.R., Turner, P. \& Gale, E.A.M. Intraocular pressure and pupillary responses in patients with diabetes mellitus. Postgrad Med J 1991, 67: 250-251.

13. Wollner, L. Ageing of the autonomic nervous system. Med Internat 1983, 1: 1711-1714. 